\title{
Risk Differences between Elderly Men and Women toward Doctor-Diagnosed Diabetes Mellitus in Urban Areas in Indonesia: 2013 National Basic Health Research Data
}

\author{
Perbedaan Risiko antara Laki-laki dan Perempuan Lanjut Usia terhadap \\ Diabetes Melitus dengan Diagnosis Dokter di Wilayah Perkotaan di \\ Indonesia: Data Riset Kesehatan Dasar Tahun 2013
}

\author{
Meiwita Paulina Budiharsana
}

Department of Biostatistics and Population Studies, Faculty of Public Health Universitas Indonesia, Depok, Indonesia

\begin{abstract}
Diabetes mellitus (DM) is one of the most common non-communicable diseases (NCDs) in Indonesia. Reportedly that DM is associated with various risk factors. Notably, it seems that the rising prevalence rates reflect changes in urban lifestyle. This study aimed to examine risk differences in the prevalence of DM among men and women aged 15 years and older that lived in urban areas in Indonesia. Analysis used secondary data of 2013 National Basic Health Research, which applied a cross-sectional study design. The total of sample was 333,731 respondents. Data processing and analysis used multiple logistic regression method. In general, findings showed that doctor-diagnosed diabetes mellitus (DDDM) among urban men and women aged 15-39 years did not differ. However, the odds ratio of DDDM among older women aged 50-64 years was 30 times higher than women aged 15-39 years, while among the same age men was 21 times higher than younger men aged 15-39 years ( $p$ value $<0.001$ ). In conclusion, entering the age of 50 years, women show a much higher risk of contracting DDDM than women with younger age, also much higher than older men towards younger men.
\end{abstract}

Keywords: Age, diabetes mellitus, men, urban, women

\begin{abstract}
Abstrak
Diabetes melitus (DM) adalah salah satu penyakit tidak menular yang paling umum di Indonesia. DM disebabkan berbagai faktor risiko. Peningkatan prevalensi DM salah satunya disebabkan oleh perubahan gaya hidup di perkotaan. Penelitian ini bertujuan untuk menguji perbedaan prevalensi DM yang didiagnosis dokter pada laki-laki dan perempuan usia 15 tahun keatas yang tinggal di daerah perkotaan di Indonesia. Analisis menggunakan data sekunder Riset Kesehatan Dasar (Riskesdas) 2013 dengan desain studi potong lintang. Total sampel sebanyak 333.731 responden. Metode analisis menggunakan regresi logistik ganda. Hasil menunjukkan bahwa DM yang didiagnosis dokter pada laki-laki dan perempuan usia 15-39 tahun di perkotaan tidak berbeda. Meski demikan, memasuki kurun usia 50-64 tahun, responden perempuan menunjukkan risiko terdiagnosis DM 30 kali lebih tinggi dibandingkan perempuan berusia 15-39 tahun, sementara laki-laki berusia 50-64 tahun berisiko 21 kali lebih tinggi dari laki-laki berusia 15-39 tahun (nilai p<0,001). Penelitian ini menyimpulkan perempuan yang memasuki usia 50 tahun berisiko terkena DM jauh lebih besar dari pada perempuan yang berusia lebih muda dan risiko ini lebih besar daripada laki-laki berusia lanjut terhadap laki-laki berusia lebih muda.
\end{abstract}

Kata Kunci: Usia, diabetes melitus, laki-laki, perkotaan, perempuan

How to Cite: Budiharsana MP. Risk differences between elderly man and women toward doctor-diagnosed diabetes mellitus in urban areas in Indonesia: 2013 National Basic Health Research Data. Kesmas: National Public Health Journal. 2017; 12(1): 15-21. (doi:10.21109/kesmas.v12i1. 1436)
Correspondence: Meiwita Paulina Budiharsana, Biostatistics and Population Studies Department, Faculty of Public Health, Building A 2nd floor, Universitas Indonesia, Phone: +6221-7871636, e-mail: mbudiharsana@gmail.com Received: February 23rd 2017

Revised: May $1^{\text {st }} 2017$

Accepted: July $10^{\text {th }} 2017$ 


\section{Introduction}

The rising prevalence of diabetes mellitus has positioned this disease as one of the most common non-communicable diseases (NCDs) in Indonesia. With a population of over 237 million according to the 2010 Population Census, the epidemiology of diabetes in this country will certainly affect the epidemiology of diabetes in the Asia-Pacific region. ${ }^{1}$ The rising prevalence of diabetes in newly industrialized nations such as Indonesia will be at a very rapid rate and become a double burden if development is patchy but occurred rapidly. ${ }^{2}$ While some parts of Indonesia remain having high infectious diseases, other parts of the country showing a transition to NCDs. Indonesia is experiencing the epidemiological transition, where the prevalence of both communicable and non-communicable diseases are high. ${ }^{3}$

Diabetes is defined by the World Health Organization (WHO) as a chronic disease that occurs either when the pancreas does not produce enough insulin or when the body cannot effectively use the insulin it produces. Insulin is a hormone that regulates blood sugar. Type 1 diabetes (previously known as insulin-dependent, juvenile or childhood-onset) is characterized by deficient insulin production and requires daily administration of insulin. Type 2 diabetes (formerly called non-insulin-dependent or adult-onset) results from the body's ineffective use of insulin. ${ }^{4}$ Type 2 diabetes comprises the majority of people with diabetes around the world, and is largely the result of overweight and physical inactivity. More frequently, the most prominent risk factor, which is obesity, is more common in women. ${ }^{5,6}$ Because type 2 diabetes shows less marked symptoms, the disease may be diagnosed several years after onset, or when complications have already arisen. Recently, type 2 of diabetes was not only seen in adults, but it also occurs increasingly among children. ${ }^{7-9}$

The danger of being unaware of having diabetes is in the fact that raised blood sugar (hyperglycemia) over time can damage the nerves, blood vessels, heart, eyes and kidneys. ${ }^{10}$ Adults with diabetes have a 2-3 fold increased risk of heart attacks and strokes. Combined with reduced blood flow, neuropathy (nerve damage) in the feet increases the chance of foot ulcers, infection and eventual need for limb amputation. In addition, diabetic retinopathy caused blindness, due to a long-term accumulated damage to the small blood vessels in the retina. Diabetes is also among the leading causes of kidney failure. ${ }^{4,11}$

The government through the Ministry of Health had issued a decree known as the Regulation of Minister of Health No. 43/2016 that included type 2 diabetes in the Minimum Standard Services, or a disease to be detected and treated early at primary care level facilities. Together with the national promotion for healthy environment, the
Ministry of Health had initiated Germas, the People's Healthy Lifestyle Movement in ten provinces in November 2015 in aim to change people's behavior and encourage people to adopt a healthier lifestyle. Prevention of NCDs (such as type 2 diabetes and hypertension) was prioritized. This movement was expanded nationwide with the followed issuance of the Presidential Instruction (Inpres) No. 1/2017 on Germas. Specific activities included efforts to increase people's awareness to stay healthy, to adopt a clean and healthy lifestyle, and to have a willingness to maintain the cleanliness of their environment. Referring to expenditure data from the National Health Insurance program, which is managed by the Social Security Organizing Body (well-known as BPJS), the Ministry of Health specifically targeted the prevention and early detection of NCDs, such as diabetes, hypertension, heart problems, kidney failures and cancer because these NCDs will consume most of the BPIS budget at present and in the future.

Indeed, simple lifestyle measures have been shown to be effective in preventing or delaying the onset of type 2 diabetes. The WHO's 'Global strategy on diet, physical activity and health' focuses on population-wide approaches to promote healthy diet and regular physical activity, thereby reducing the growing global problem of obesity. ${ }^{12}$ In childhood, almost all cases of diabetes are type 1 diabetes, whereas later in life there is a rapid increase in type 2 diabetes. Recent study pointed that type 2 diabetes mellitus (DM) is no longer considered a disease exclusively found in adults. ${ }^{13}$ In reverse, a study presented at the 2016 European Association for the Study of Diabetes (EASD) 2016 Annual Meeting pointed out that the onset of type 1 diabetes is just as likely to occur in people older than 30 years of age as in those younger. Thomas NJM said that, "even people who develop type 1 diabetes in childhood or adolescence are often recoded in their medical record as having type 2 when they become adults".14

Public health messages are necessary to promote people to achieve and maintain healthy body weight; be physically active (at least 30 minutes of regular, moderate-intensity of activity in most days); eat a healthy diet, avoiding sugar and saturated fats intake; and avoid tobacco use because smoking increases the risk of diabetes. ${ }^{15} \mathrm{WHO}$ also recommends countries to implement early diagnosis through relatively inexpensive testing of blood sugar. ${ }^{11}$ However, it is unknown whether this test is already available at all community health centers or private health care provider practitioners in Indonesia.

DM affects more than 35 million Indonesians, urban and rural, according to the 2013 National Basic Health Research. ${ }^{1,16}$ When examining people aged 15 years and older in urban areas in Indonesia, the 2013 National Basic Health Research showed a prevalence of 1.5\% doc- 
tor-diagnosed diabetes mellitus (DDDM), an increasing trend from the reported prevalence of $0.7 \%$ in the 2007 National Basic Health Research.6,17 The prevalence of diabetes in Indonesia is limited to type 2 DM (adult-onset) because the estimates of diabetes prevalence for type 1 do not exist.

The 2013 National Basic Health Research reported that in both urban and rural areas, women showed a higher prevalence of DDDM than men. The prevalence of DDDM among women 15 years and older was $1.7 \%$ (out of a total sample of 374,506 women), compared to the prevalence of DDDM among men of similar age-group of $1.4 \%$ (out of a total sample of 347,823 men). ${ }^{16}$ The aim of this study was to explore further risk differences by age groups, to determine the exact age that urban women and men differed at risk of contracting diabetes. Based on this finding, specific public health policy and messages could be directed towards urban women before they entered a higher-risk age group.

\section{Method}

The 2013 National Basic Health Research data of urban population aged 15 years and older were used in the assumption that the possibility of being diagnosed properly by doctors and other trained health care providers would be more accurate in urban areas of Indonesia. The 2013 National Basic Health Research was conducted by the Agency for Health Research and Development, under the Ministry of Health of Indonesia. It was a cross-sectional survey that aimed to portrait the health problems at province and district levels. Data collection was conducted between May - June 2013 in all 33 provinces, with a sample of 294,959 households in 497 districts /municipalities. To assess the diabetes situation, the 2013 National Basic Health Research interviewed a sample of 722,329 respondents consisting of 347,823 men and 374,506 women aged 15 years and older. This sample was large enough to assume that the prevalence of DDDM in this study was close to the real prevalence in the population. This study used sample size formula for DDDM as a qualitative variable or a proportion of men and women with DDDM in urban areas in Indonesia for cross-sectional surveys. In this analysis, this study took all of the sample of 333,731 respondents aged 15 years and older who lived in urban area. Out of this sample population, 159,227 men and 174,504 women were examined whether they already had DDDM. This study did not examine the respondents who were categorized as having "undiagnosed diabetes" or never been told by a doctor that they had diabetes.

Five selected socio-demographic variables were age at the date of interview (categorized into 15-39 years, 4049 years, 50-64 years, 65 years and older); education categorized into high level (completed senior high school, or completed academy and university) and low level (no education, some primary, completed primary or completed junior high school); employment status (employed or unemployed); health insurance coverage (categorized as owning privately purchased insurance, or other employer-based health insurance, or not having at all); and the wealth index that was constructed using principle components analysis based on housing characteristics and assets by National Basic Health Research. The National Basic Health Research wealth index was constructed with the Principal Component Analysis (PCA) using the 2010 National Socioeconomic Survey (SUSENAS)' twelve parameters of source of drinking water, cooking fuel, owning defecation facility, type of latrines, septic tank or others, electricity, motorbike, television, water heater, LPG $12 \mathrm{~kg}$ tank, refrigerator and owning $\operatorname{car}(\mathrm{s})$. The PCA scores were regarded as having $53.6 \%$ 'proportion explained' of the expenditures. Estimates of socioeconomic status were categorized in wealth quintiles index ( $1=$ lowest, $2=$ low-middle, $3=$ middle, $4=$ mid-upper and $5=$ highest). 16

Statistical analysis was performed using statistical software. Data were weighted by National Basic Health Research on the basis of complex sample design. Adjusted odds ratios were calculated using multivariate logistic regressions to explain the factors associated with DDDM by sex separately. The covariates were age, education, employment status, wealth index, and owning any type of health insurance.

Ethical approval was obtained from the Health Research Ethics Committee of the National Institute of Health Research and Development Ministry of Health (Komisi Etik Penelitian Kesehatan, Badan Litbangkes Kementerian Kesehatan RI) No.LB.02.01/5.2/ KE.006/2013, and a written informed consent was obtained from all Biomedical survey respondents by the National Institute of Health Research and Development Ministry of Health interviewers.

This study was limited to analyzing only available variables in the 2013 National Basic Health Research dataset. The explanatory variables were restricted to age, education, employment status, wealth index and owning health insurance. However, the dependent variable of DDDM was perceived sufficient for developing a public health intervention to warn urban women and men about the critical age to get an examination and a doctor's diagnosis. Future study on diabetes in Indonesia should help identify whether diabetes patients have sufficient knowledge about her/his disease, by province and insurance type, to inform policies or practices that will help improve diabetes outcomes among low economic populations. For study with primary data, it is strongly recommended to add weight and height add measures, and calculate body mass index. 
Results

\section{Characteristics of the Participants}

Out of a total of 333,731 respondents, only $2 \%$ persons aged 15 years or older admitted that they already had DDDM. Table 1 presents that the age of most sampled population was in the 15-39 age groups (60.5\%), more than half $(55 \%)$ had lower than senior high school education, and $42.9 \%$ were unemployed. Most of respondents were in the fourth and highest quintile of wealth index $(63.4 \%)$, and $50.5 \%$ respondents stated that they owned some kind of health insurance at the time of survey.

Table 2 and Table 3 show that the odds of having
DDDM were substantial within the age of 50-64 years, when compared to the reference age group of 15-39 years, with women aged 50-64 years showed a higher odds ratio than men of similar age group. Interestingly, up to the age of 40-49 years, and after $65+$ years, the odds were almost equal for men and for women. In men aged 50-64 years and 65+ years, the odds of contracting DDDM were about the same. In women, the difference was quite big, very high in women aged 50-64 years (OR $=30)$ and lower in women aged $65+$ years $(O R=20.6)$. Higher education was a slightly higher risk on men, but was not significantly associated with DDDM on women. Similarly, being unemployed showed a higher DDDM

\begin{tabular}{|c|c|c|}
\hline Socio-demographic Variables & Category & $\%$ \\
\hline \multirow[t]{2}{*}{ Diabetes } & Never diagnosed & 98.0 \\
\hline & Doctor-diagnosed & 2.0 \\
\hline \multirow[t]{4}{*}{ Age (years) } & $15-39$ & 60.5 \\
\hline & $40-49$ & 19.2 \\
\hline & $50-64$ & 15.3 \\
\hline & $65+$ & 6.0 \\
\hline \multirow[t]{2}{*}{ Education level } & $\begin{array}{l}\text { High (completed senior high school, academic, } \\
\text { university) }\end{array}$ & 45.0 \\
\hline & $\begin{array}{l}\text { Low (no education, some primary, completed primary, } \\
\text { junior high school) }\end{array}$ & 55.0 \\
\hline \multirow[t]{2}{*}{ Employment status } & $\begin{array}{l}\text { Employed (claimed to spend most time for earning } \\
\text { money during the time of interview) }\end{array}$ & 57.1 \\
\hline & $\begin{array}{l}\text { Unemployed (claimed to look for a job or being } \\
\text { at school or retiree during the time of interview) }\end{array}$ & 42.9 \\
\hline \multirow[t]{5}{*}{ Wealth index } & Lowest & 4.0 \\
\hline & Low-middle & 10.8 \\
\hline & Middle & 21.7 \\
\hline & Mid-upper & 32.4 \\
\hline & Highest & 31.0 \\
\hline \multirow[t]{2}{*}{ Health insurance coverage } & Not own & 49.5 \\
\hline & $\begin{array}{l}\text { Own any health insurance (such as Askes/JPK/PNS/ } \\
\text { Veteran/Pension, JPK, Jamsostek, private or } \\
\text { company-based insurance, Jamkesmas and Jamkesda) }\end{array}$ & 50.5 \\
\hline
\end{tabular}

Table 2. Risk Factors of Urban Men with Doctor-Diagnosed Diabetes Mellitus

\begin{tabular}{|c|c|c|c|c|c|c|}
\hline \multirow{3}{*}{$\begin{array}{l}\text { Socio-demographic } \\
\text { Variables }\end{array}$} & \multirow{3}{*}{ Category } & \multicolumn{5}{|c|}{ Men $(n=159,227)$} \\
\hline & & \multirow{2}{*}{$\begin{array}{l}\% \\
\text { DDDM }\end{array}$} & \multicolumn{2}{|c|}{ Unadjusted } & \multicolumn{2}{|r|}{ Adjusted* } \\
\hline & & & p-value & OR $(95 \% \mathbf{C I})$ & p-value & OR $(95 \% \mathrm{CI})$ \\
\hline \multirow[t]{4}{*}{ Age } & $15-39$ & 0.3 & & 1 & & 1 \\
\hline & $40-49$ & 2.4 & $<0.001$ & $7.80(6.10-9.80)$ & $<0.001$ & $8.90(6.90-11.50)$ \\
\hline & $50-64$ & 5.7 & $<0.001$ & $19.00(15.20-23.60)$ & $<0.001$ & $21.30(16.90-26.80)$ \\
\hline & $65+$ & 5.9 & $<0.001$ & $19.70(15.50-24.90)$ & $<0.001$ & $22.10(17.40-28.10)$ \\
\hline \multirow[t]{2}{*}{ Education level } & High & 2.0 & & 1 & & 1 \\
\hline & Low & 1.7 & 0.005 & $0.80(0.80-0.90)$ & $<0.001$ & $0.80(0.70-0.90)$ \\
\hline \multirow[t]{2}{*}{ Employment status } & Employed & 1.7 & & 1 & & 1 \\
\hline & Unemployed & 2.3 & $<0.001$ & $1.40(1.20-1.50)$ & $<0.001$ & $1.60(1.40-1.90)$ \\
\hline \multirow[t]{5}{*}{ Wealth index } & Lowest & 0.7 & & 1 & & 1 \\
\hline & Low-middle & 0.9 & $<0.001$ & $1.30(0.80-2.00)$ & $<0.001$ & $1.40(0.90-2.20)$ \\
\hline & Middle & 1.1 & $<0.001$ & $1.60(1.10-2.30)$ & $<0.001$ & $1.90(1.30-2.80)$ \\
\hline & Mid-upper & 1.9 & $<0.001$ & $2.70(1.90-4.00)$ & $<0.001$ & $3.40(2.30-4.90)$ \\
\hline & Highest & 2.8 & $<0.001$ & $4.30(2.90-6.20)$ & $<0.001$ & $4.40(3.00-6.50)$ \\
\hline \multirow[t]{2}{*}{ Health insurance coverage } & Not at all & 1.7 & & 1 & & 1 \\
\hline & Own any health insurance & 2.0 & $<0.001$ & $1.20(1.10-1.40)$ & 0.496 & $1.04(0.90-1.20)$ \\
\hline
\end{tabular}

Note: *Adjusted by logistic regression 
Table 3. Risk Factors of Urban Women with Doctor-Diagnosed Diabetes Mellitus

\begin{tabular}{|c|c|c|c|c|c|c|}
\hline \multirow{3}{*}{$\begin{array}{l}\text { Socio-demographic } \\
\text { Variables }\end{array}$} & \multirow{3}{*}{ Category } & \multicolumn{5}{|c|}{ Women $(n=174,504)$} \\
\hline & & \multirow{2}{*}{$\begin{array}{c}\% \\
\text { DDDM }\end{array}$} & \multicolumn{2}{|c|}{ Unadjusted } & \multicolumn{2}{|c|}{ Adjusted $*$} \\
\hline & & & p Value & OR $(95 \% \mathbf{C I})$ & p Value & OR $(95 \% \mathrm{CI})$ \\
\hline \multirow[t]{4}{*}{ Age } & $15-39$ & 0.3 & & 1 & & 1 \\
\hline & $40-49$ & 2.9 & $<0.001$ & $8.5(7.1-10.3)$ & $<0.001$ & $8.6(7.1-10.4)$ \\
\hline & $50-64$ & 7.1 & $<0.001$ & $22.2(18.5-26.6)$ & $<0.001$ & $30.0(7.2-23.0)$ \\
\hline & $65+$ & 6.0 & $<0.001$ & $18.3(15.1-22.2)$ & $<0.001$ & $20.6(16.8-25.2)$ \\
\hline \multirow[t]{2}{*}{ Education } & High & 11.6 & & 1 & & 1 \\
\hline & Low & 2.6 & $<0.001$ & $1.6(1.4-1.8)$ & 0.687 & $1.03(0.9-1.2)$ \\
\hline \multirow[t]{2}{*}{ Employment status } & Employed & 1.8 & & 1 & & 1 \\
\hline & Unemployed & 2.4 & $<0.001$ & $1.3(1.2-1.5)$ & $<0.001$ & $1.3(1.2-1.5)$ \\
\hline \multirow[t]{5}{*}{ Wealth index } & Lowest & 0.7 & & 1 & & 1 \\
\hline & Low-middle & 1.4 & $<0.001$ & $2.1(1.4-3.0)$ & $<0.001$ & $2.5(1.7-3.6)$ \\
\hline & Middle & 1.8 & $<0.001$ & $2.7(1.9-3.7)$ & $<0.001$ & $3.6(2.6-5.1)$ \\
\hline & Mid-upper & 2.3 & $<0.001$ & $3.5(2.5-4.9)$ & $<0.001$ & $5.5(3.9-7.7)$ \\
\hline & Highest & 2.8 & $<0.001$ & $4.2(3.0-5.9)$ & $<0.001$ & $6.4(4.6-9.1)$ \\
\hline \multirow[t]{2}{*}{ Health insurance coverage } & Not at all & 2.0 & & 1 & & 1 \\
\hline & Own any health insurance & 2.4 & $<0.001$ & $1.3(1.1-1.4)$ & $<0.001$ & $1.2(1.1-1.3)$ \\
\hline
\end{tabular}

Note: *Adjusted by logistic regression

risk on men than on women. Owning any health insurance did not make too much a difference although the correlation was statistically significant. And although both sexes showed that DDDM risk rose with rising wealth status, the risk was found higher in women than in men.

\section{Discussion}

Indonesian urban women performed a higher prevalence of DDDM than men, and contracted diabetes at an earlier age because the peak of DDDM prevalence among women was at earlier age group of 50-64 years $(7.1 \%)$. Urban men showed the peak prevalence at the age of $65+$ years $(5.9 \%)$. This pattern differs than the common pattern in other countries, where diabetes tends to affect men more than women. ${ }^{18,19}$

This is a troubling fact because women with diabetes may have been due to increased women's obesity after age of 50 years. Differences in physiology of men and women, and the sex hormones estrogen and testosterone are the key to why women with diabetes are more vulnerable than men with diabetes. At the time women get to menopause, a time when estrogen levels fall and women, at least hormonally speaking, become more like men, women with diabetes are just as likely to get kidney disease as men regardless of age. Lower estrogen levels are associated with kidney disease, although it is still unknown whether there is a cause-effect relationship and more study is needed to validate such an approach. ${ }^{20}$ Thus, against the general belief that women live longer than men, once women get diabetes, diabetes increases the risk for kidney diseases. In fact, women with diabetes are more likely than men with the disease to have poor blood glucose control, have high blood pressure and un- healthy cholesterol levels. Recently, it has been shown that among older patients with type 2 diabetes and endstage renal disease (ESRD), mortality rates were higher among women than men. ${ }^{21}$

Finding also showed that education (level of schooling) was not a significant predictor among urban women; while in other countries education is a highly significant predictors of quality of life among women with type 2 diabetes as compared to men. ${ }^{19}$ This means that the people's knowledge about type 2 diabetes needs to be enhanced through public health education. Messages about the need for caloric reduction, increased physical activity and specific assistance to achieve modest weight loss should reach women and men. Creative new ways to implement such primary prevention strategies at community level, initiated by a primary health care is a possibility for immediate action. Overall, it is important to disseminate a public health message to women before they reach the age of 50 years. Information on prevention of type 2 diabetes through lifestyle modification is beyond the influence of medical care practitioners anyway, and are likely to be more amenable to public health efforts. ${ }^{22}$

Study found that being unemployed was a predictor of type 2 diabetes. This association had been supported for many years as presented by the classic literature which described the association between depression and unemployment with diabetes. ${ }^{23}$ Recent study in Malaysia pointed out that being unemployed means less physical activity. The odds of having poor glycemic control in people who rarely did exercise or were less physically active were significant. ${ }^{24}$ Wealth status represented a life-course socio-economic status (SES) of a person. Diabetes incidence was inversely associated wealth status as lifecourse SES affected the long-term nutritional status of a 
person, by the habit of consuming excessive amounts of refined grains, sugar-sweetened beverages, red and processed meat and others with the opposite effects of healthy eating. ${ }^{25,26}$

Having all of the risk factors, the public need to get information that the essential medicines and basic technologies for early detection, diagnosis and monitoring of diabetes at primary care level are now available. ${ }^{27,28}$ Indonesia is already capable to procure the three essential medicines for diabetes management, namely insulin, metformin and sulphonylurea(s). ${ }^{4}$ Nonetheless, prevention and early detection are still much better.

\section{Conclusion}

Type 2 diabetes will develop into a national public health problem in Indonesia. Findings from this study indicate that age, employment status and wealth status are factors associated with DDDM for urban men and women in Indonesia. Women aged 50-64 years appear to be at highest risk $(\mathrm{OR}=30 ; 95 \% \mathrm{CI}=7.2-23.0)$. For men, the risks seem to be the same at the age of 50-64 years and when older $(65+)$, with overall risks lower than women of these age-groups $(\mathrm{OR}=21.3 ; 95 \% \mathrm{CI}=16.9$ $26.8)$ and $(\mathrm{OR}=22.1 ; 95 \% \mathrm{CI}=17.4-28.1)$. Considering that the lifetime hazard probability of being diagnosed with diabetes mellitus is substantial, it is important to educate the public about how to prevent type $2 \mathrm{DM}$. Furthermore, evidence from National Basic Health Research data underscore the need for women to receive public health messages on how to prevent, detect and manage diabetes before they reach the age of 50 . Policies that support diabetes screening among women close to menopausal age are also important.

\section{Recommendation}

Short-term recommendation is directed toward improving access to receiving DDDM for all. This will serve as the basis for improvement of treatment and higher control of diabetes-related complications. In the long run, diabetes and its complications impact harshly on the finance of individuals and their families. Long-term recommendation is related to comply to standard guidelines in preventing, detecting, diagnosing and treating type 2 diabetes, as parts of efforts to attain the Sustainable Development Goals by 2030 (Goal 3.4 to reduce by one-third premature mortality from NCDs including DM through prevention and treatment). Indonesia needs to gather more accurate data on the prevalence of type 2 diabetes and to monitor the application of standard treatment regimen that meets the standard guidelines to assure treatment effectiveness. By understanding the associations between age and the prevalence of type 2 diabetes among men and women, public health program interventions and community health pre- vention messages can be designed more effectively.

\section{Acknowledgment}

Febrina M. Damanik and Kanya Anindya contributed their time to data processing and analysis, and Besral, Poppy Yuniar and Milla Herdayanti from Department of Biostatistics and Population Studies, Faculty of Public Health Universitas Indonesia provided valuable inputs in the drafting of this article.

\section{References}

1. Statistics Indonesia (Badan Pusat Statistik/BPS). Penduduk menurut umur tunggal, daerah perkotaan/pedesaan dan jenis kelamin Indonesia [Internet]. 2010 [cited 2016 Dec 15]. Available from: https://sp2010.bps.go.id/index.php/site/tabel?searchtabel=Penduduk+Menurut+Umur+Tunggal\%2C+Daerah+Perkotaan $\%$ 2 FPerdesan $\% 2 \mathrm{C}+$ dan + Jenis + Kelamin\&tid $=262 \&$ search wilayah=Indonesia\&wid=0000000000\&lang=id

2. Hu FB. Globalization of diabetes: the role of diet, lifestyle, and genes. Diabetes Care [serial on internet]. 2011 [cited 2016 JUn 5]; 34(6): 1249-57. Available from: http://www.ncbi.nlm.nih.gov/ pmc/articles/PMC3114340/

3. Soewondo P, Ferrario A, Tahapary DL. Challenges in diabetes management in Indonesia: a literature review. Global Health [serial on internet]. 2013 Dec 3 [cited 2016 Dec 5]; 9: 63. Available from: http:// eprints.lse.ac.uk/54898/

4. WHO. Global report on diabetes. Vol. 978, World Health Organization. [homepage on internet]. 2016 [cited 2017 Jan 5]. Available from: http://www.who.int/about/licensing/\%5Cnhttp://apps.who.int/iris/bitstream/10665/204871/1/9789241565257_eng.pdf

5. Kautzky-Willer A, Harreiter J, Pacini G. Sex and gender differences in risk, pathophysiology and complications of type 2 diabetes mellitus. Endocrine Reviews [serial on internet]. 2016 Jun [cited 2017 Feb 4]; 37(3): 278-316. Available from: http://www.ncbi.nlm.nih.gov/ pubmed/27159875

6. Lovejoy JC, Sainsbury A. The stock conference 2008 working group. Sex differences in obesity and the regulation of energy homeostasis. Obesity Reviews [serial on internet]. 2009 [cited 2016 Jun 5]; 10(2): 154-67. Available from: http://dx.doi.org/10.1111/j.1467-789X.2008.00529.x

7. Haines L, Wan KC, Lynn R, Barrett TG, Shield JPH. Rising incidence of type 2 diabetes in children in the U.K. Diabetes Care [serial on internet]. 2007 [cited 2016 Jun 6]; 30(5): 1097-101. Available from: http://care.diabetesjournals.org/content/30/5/1097

8. Rosenbloom AL, Silverstein JH, Amemiya S, Zeitler P, Klingensmith GJ. Type 2 diabetes in children and adolescents. Pediatric Diabetes [serial on internet]. 2009 [cited 2016 Apr 5]; 10: 17-32. Available from: http://dx.doi.org/10.1111/j.1399-5448.2009.00584.x

9. Dabelea D, Mayer DEJ, Saydah S, Imperatore G, Lindewr B, Divers J, al et. Prevalence of type 1 and type 2 diabetes among children and adolescents from 2001 to 2009. JAMA [serial on internet]. 2014 May 7 [cited 2016 Apr 5]; 311(17): 1778-86. Available from: http://dx.doi.org/10.1001/jama.2014.3201

10. Orasanu G, Plutzky J. The pathologic continuum of diabetic vascular disease. Journal of American College of Cardiology [serial on internet]. 
2009 [cited 2016 Jun 6] Feb 3; 53(5, Supplement): S35-42. Available from: http://www.sciencedirect.com/science/article/pii/S07 35109708037558

11. WHO. Diabetes fact sheet [manuscript on internet]. 2016 [cited 2016 Jun 5]. Available from: http://www.who.int/mediacentre/fac tsheets/fs312/en/

12. World Health Organization. The global strategy on diet, physical activity and health [manuscript on internet]. WHO. 2015 [cited 2017 Apr 23]. Available from: http://www.who.int/nmh/wha/59/dpas/en/

13. ICD10-Data. Type 2 diabetes mellitus [manuscript on internet]. [cited 2016 Dec 15]. Available from: http://www.icd10data.com/ ICD10CM/Codes/E00-E89/E08-E13/E11.

14. Thomas NJ. Half of all type 1 diabetes develops after 30 years of age [manuscript on internet]. 2016 [cited 2016 Dec 15]. Available from: http://www.medscape.com/viewarticle/869028.

15. Blair SN, Sallis RE, Hutber A, Archer E. Exercise therapy - the public health message. Scandinavian Journal of Medicine and Science Sports [serial on internet]. 2012 [cited 2016 Jun 4]; 22(4): e24—e28. Available from: http://dx.doi.org/10.1111/j.1600-0838.2012.01462.x.

16. Badan Penelitian dan Pengembangan Kesehatan Kementerian Kesehatan. Riset Kesehatan Dasar tahun 2013. Jakarta: Kementerian Kesehatan. Jakarta: Kementerian Kesehatan Republik Indonesia; 2013.

17. Mihardja L, Soetrisno U, Soegondo S. Prevalence and clinical profile of diabetes mellitus in productive aged urban Indonesians. Journal of Diabetes Investigation [serial on internet]. 2014 Sep [cited 2016 Dec 15]; 5(5): 507-12. Available from: http://doi.wiley.com/10.11 11/jdi.12177.

18. Roche MM, Wang PP. Factors associated with a diabetes diagnosis and late diabetes diagnosis for males and females. Journal of Clinical and Translational Endocrinology [serial on internet]. 2014 [cited 2016 Jun 5] Sep; 1(3): 77-84. Available from: http://www.sciencedirect.com/science/article/pii/S2214623714000234.

19. D’Souza MS, Venkatesaperumal R, Ruppert SD, Karkada SN, Jacob D, Jacob D. Health related quality of life among omani men and women with type 2 diabetes. Journal of Diabetes Research [serial on internet]. 2016 [cited 2017 Apr 29]; 2016: 1-10. Available from: http://www.hindawi.com/journals/jdr/2016/8293579/.

20. Erika Gebel. How diabetes differs for men and women: Diabetes Forecast ${ }^{\circledR}$ [manuscript on Internet]. 2011 [cited 2017 Apr 27]. Available from: http://www.diabetesforecast.org/2011/oct/how-dia- betes-differs-for-men-and-women.html?referrer=https://www.google. co.id/.

21. Narres M, Claessen H, Droste S, Kvitkina T, Koch M, Kuss O, et al. The incidence of end-stage renal disease in the diabetic (compared to the non-diabetic) population: a systematic review. PLoS One [serial on internet]. 2016 Jan 26 [cited 2017 Apr 29]; 11(1): e0147329. Available from: http://dx.plos.org/10.1371/journal.pone.0147329.

22. Green LW, Brancati FL, Albright A. Primary prevention of diabetes working group. primary prevention of type 2 diabetes: integrative public health and primary care opportunities, challenges and strategies. Family Practice [serial on internet]. 2012 Apr 1 [cited 2017 Apr 29]; 29(suppl 1): i13-23. Available from: http://www.ncbi.nlm.nih.gov/ pubmed/22399542.

23. Friis R, Nanjundappa G. Diabetes, depression and employment status. Social Science \& Medicine [serial on internet]. 1986 [cited $2017 \mathrm{Apr}$ 29]; 23(5): 471-5. Available from: http://www.ncbi.nlm.nih.gov/ pubmed/3764497.

24. Firouzi S, Barakatun-Nisak MY, Azmi KN. Nutritional status, glycemic control and its associated risk factors among a sample of type 2 diabetic individuals, a pilot study. Journal of Research in Medical Science [serial on internet]. 2015 Jan [cited 2017 Apr 29]; 20(1): 40-6. Available from: http://www.ncbi.nlm.nih.gov/pubmed/25767521.

25. Wu Y, Ding Y, Tanaka Y, Zhang W. Risk factors contributing to type 2 diabetes and recent advances in the treatment and prevention. International Journal of Medicine Science [serial on internet]. 2014 [cited 2017 Apr 29]; 11(11): 1185-200. Available from: http://www.ncbi. nlm.nih.gov/pubmed/25249787.

26. Stringhini S, Zaninotto P, Kumari M, Kivimäki M, Batty GD. Lifecourse socioeconomic status and type 2 diabetes: the role of chronic inflammation in the English longitudinal study of ageing. Scientific Reports [serial on internet]. 2016 Jul 22 [cited 2017 Apr 29]; 6(1): 24780. Available from: http://www.nature.com/articles/srep24780.

27. Robertson J, Macé C, Forte G, de Joncheere K, Beran D. Medicines availability for non-communicable diseases: the case for standardized monitoring. Global Health [serial on internet]. 2015 [cited 2017 Jan 5]; 11(1): 18. Available from: http://dx.doi.org/10.1186/s12992-0150105-0.

28. Bazargani YT, de Boer A, Leufkens HG, Mantel-Teeuwise Ak. Selection of essential medicines for diabetes in low and middle income countries: a survey of 32 national essential medicines lists. PLoS One. 2014; 9: 9. 